
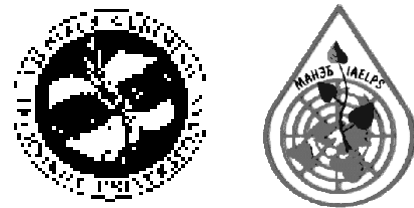

JOURNAL OF ENVIRONMENTAL ENGINEERING

AND LANDSCAPE MANAGEMENT

http:/www.vtu.lt/english/editions

2004, Vol XII, No 3, 79-84

\title{
EXPERIMENTAL STUDY AND MATHEMATICAL MODELLING OF BIOFILTER AERODYNAMIC RESISTANCE
}

\author{
Pranas Baltrẻnas, Rasa Vaiškūnaitė, Valdas Špakauskas \\ Dept of Environmental Protection, Vilnius Gediminas Technical University, \\ Saulètekio al.11,LT-10223 Vilnius-40,Lithuania.E-mail: aak@ap.vtu.lt, rasava@takas.lt \\ Received 16 Mar 2004; accepted 21 May 2004
}

\begin{abstract}
Development of industry is not always accompanied with the implementation of clean technologies, thus the problem of air and water purification remains. For the moment, pollution with different paint components is widely spread and hard to be solved. A biofilter was developed at the Department Environmental Protection of Vilnius Gediminas Technical University (VGTU), and its chemical and physical purification principles and properties are analysed in works [1-3]. Besides the efficiency of pollutant cleaning, the characteristics of filter aerodynamic resistance are also essential, therefore, the aerodynamic properties of the biofilter are analysed in this work. For anticipation and theoretical evaluation of aerodynamic processes going on in a biological air-purification device, the processes occurring in the object being investigated - a biofilter - were modelled with the help of Phoenics, Versions 3.2 and 3.5. Aerodynamic processes - in-coming flow velocity and aerodynamic charge resistance - were analysed with the help of the software package Phoenics, Versions 3.2 and 3.5. Modelling was based on mathematical equations that describe physical laws.
\end{abstract}

Keywords: biofilter, mathematical model, aerodynamic resistance, empirical expression.

\section{Introduction}

Flowing through a biofilter could be treated as flowing through a porous material. In practice granular or fibre filters are usually used for the purification of dusty air. Operation of such filters is rather fully analysed in the works of VGTU as well as in other works [1-4]. However, until the last works, granular filters were used only for the purification of air polluted with aerosols and dusts. During operation of such filters both their aerodynamic resistance and efficiency were fluctuating. That was obviously related to dust sedimentation in the filter. When purifying air with the help of the filter, it is purified only from some or other polluting gaseous components, thus in the course of operation of such a filter its aerodynamic resistance remains unchanged in time, and only filter purification efficiency undergoes changes. It is a key property of the filter. As it is seen in [5-6], the efficiency of the filter depends on the pressure gradient in it, thus it is essential to have a deeper examination of these filter properties. This work is devoted for such an investigation.

\section{Investigation methods and results}

An experimental biofilter with activated charge of pine bark was developed at the Department of Environmental Protection of VGTU. The biofilter $(500 \cdot 480 \cdot 2000 \mathrm{~mm})$ with biologically activated charge contains five separate layers of biomedium.

When purifying air from the mixture of volatile compounds of an organic nature, the flow of polluted air is blown through all the five layers of biomedium by means of a ventilator. Dampers with control handles are installed in the inlet and outlet ducts of the filter to adjust air flow (from 43,2 to $144,69 \mathrm{~m}^{3} / \mathrm{h}$ ) and flow velocity (from 0,8 to $2,0 \mathrm{~m} / \mathrm{s}$ ). In order to increase the amount of polluted air, the inlet airduct has a funnel shape at the front end. Purified air is exhausted from the filter through a flexible duct.

During experiments air flow velocity was measured by a velocity meter TESTO-452 with a thermopair. When increasing the velocity of air flow injected up to $2,0 \mathrm{~m} / \mathrm{s}$, the measurement error also grows. Each measurement was repeated five times. The results of the tests performed at the laboratory are given in Fig 1. 




Fig 1. Dependence of aerodynamic resistance on the charge thickness

\section{Model of biofilter resistance}

In our case the stationary layer of a sorbent consists of different form and dimension charge elements that rm a rather complex geometric system the mathematical description of which is impossible. Porosity $\varepsilon$ is one of the main characteristics of such a filter which in our case was defined using traditional methods and is equal to 0,75 . Let's suppose that charge elements are of a round form and that their internal radius $r$ is $4 \mathrm{~cm}$ (Fig 2) [7-13].

It is obvious that, if $\mathrm{d}$ is the element diameter, then the number $\mathrm{N}$ of charge elements in the filter cross-section, the area of which is $\mathrm{S}$, is $N=\frac{a \cdot b}{d^{2}}$ or $N=\frac{S}{d^{2}}$. Then the total cross-section area of the channel through which the fluid was passing is $S_{f}=\left(1-\frac{\pi}{4}\right) \cdot S$, and, supposing that the flow is passing through cylinder capillaries (Fig 3) the effective diameter of which is def, we obtain the area of this capillary cross-section $S_{k}=\left(1-\frac{\pi}{4}\right) \cdot d^{2}$ and, at the same time, the expression

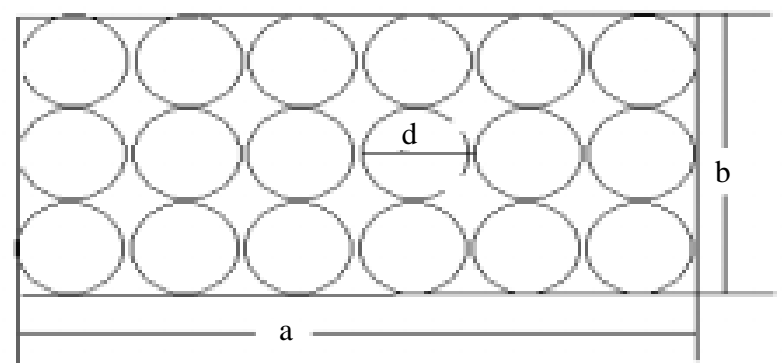

Fig 2. Model the biocharge cross-section

$a$ - fraction capillary length of the bark charge; $b$ - fraction capillary thickness of the bark charge; $d$ - fraction capillary diameter of the bark charge of the effective diameter $d_{e f}$

$$
\begin{gathered}
d_{e f}^{2}=\frac{4-\pi}{\pi} d^{2} \\
d_{e f}=0,52 d .
\end{gathered}
$$

or

It is obvious that the flow velocity in the filter, i e in a porous material, is $V_{e f}=\frac{V}{\varepsilon}$. To determine the character of the flow the effective Reinolds number is calculated $\operatorname{Re}=\frac{V_{e f} \cdot d_{e f} \cdot \rho}{\eta}$. Value $\operatorname{Re}$ is higher than the critical one, and the flow in the filter will be turbulent.

Poiseuilles Law which is valid under the streamline flow through circular tubes is expressed by:

$$
\frac{\Delta p}{\Delta X}=\frac{32 \cdot \mu}{d^{2}} \cdot U_{v} .
$$

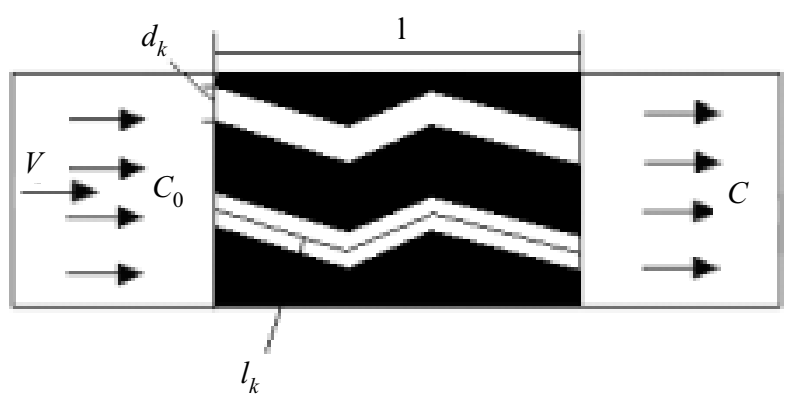

Fig 3. Air purification processes occurring in the biofilter $C_{0}$ - initial concentration of in-coming pollutants in the air, $\mathrm{mg} / \mathrm{m}^{3} ; C$ - concentration of uncleaned pollutants in the air, $\mathrm{mg} / \mathrm{m}^{3} ; V$ - velocity of the in-coming flow, $\mathrm{m} / \mathrm{s}$; 1 - thickness of the biocharge; $l_{k}$ - fraction capillary length of the bark charge, $\mathrm{mm} ; d_{k}$ - fraction capillary diameter of the bark charge, $\mathrm{mm}$ 
If a free space in the filter is assumed to consist of a series of tortuous channels, Poiseuilles Law may be rewritten for flow through the filter as:

$$
\frac{\Delta p}{\Delta X}=K \frac{\mu}{d_{e f}^{2}} U e f
$$

On the basis of the curves given in Fig 1 we make regression equations the later solution of which helps to find an empirical expression of filter aerodynamic resistance:

$$
\Delta p=0,0076 \cdot X \cdot U_{v},
$$

where the adjusted coefficient of multiple determination $R^{2}=91 \%$.

On the basis of these results the dependence of aerodynamic resistance on the filter thickness and flow velocity is illustrated in a three-dimensional graph (Fig 4).

In the course of filter operation one of the main properties of the filter, $i$ e the fluctuation of charge aerodynamic resistance during the air purification process, was determined. The biocharge aerodynamic resistance is spread over the interval from 17 to $140 \mathrm{~Pa}$.

The highest resistance of the filter charge (up to $140 \mathrm{~Pa}$ ) was recorded before all the five charge layers. The decreasing number of the charge layers resulted in gradually decreasing aerodynamic resistance. By evaluating with the help of statistical methods, very high approximation reliability coefficients $\left(R^{2}\right)$ were obtained (up to 0,99 ).

In the course of mathematical modelling, irrespective of the number of layers (in the case of one and five charge layers), the highest aerodynamic resistance of the filter was recorded in its bottom part before all the charge layers. Analogically to the results of experimental in- vestigation in the filter containing five layers aerodynamic resistance of the charge was gradually decreasing with the decrease in the number of charge layers (from 156 to $10 \mathrm{~Pa})\left(R^{2}=0,91\right)$.

$$
\frac{\Delta p}{\Delta X}=\frac{K \cdot U_{v} \cdot \mu \cdot(1-\varepsilon)^{2}}{\varepsilon^{3} \cdot r^{2}},
$$

where $K$ is the coefficient of layer resistance, $\mu$ is the dynamic coefficient of viscosity, $r$ is the radius of charge particles. Comparison with the expression (3) obtained on the basis of our experiments allows to state that $\frac{K \cdot \mu \cdot(1-\varepsilon)^{2}}{\varepsilon^{3} \cdot r^{2}}=0,0076$, and thus we obtain that $K=\frac{0,0076 \cdot \varepsilon^{3} \cdot r^{2}}{\mu \cdot(1-\varepsilon)^{2}}$.

Using the simple expression it could be determined that $K=0,456$, and the following expression could be used for modelling the aerodynamic resistance of the filter:

$$
\Delta p=\frac{0,456 \cdot U_{v} \cdot \mu \cdot(1-\varepsilon)^{2}}{\varepsilon^{3} \cdot r^{2}} X .
$$

To get full information on the flow dynamics in the filter, Navje-Stokso equations and continuity, motion amount conservation equations are used for the description of this process; the obtained equation system is solved with the help of digital methods, and information on the flow character in the filter is received with the help of Phoenics software package [13] (Fig 5).

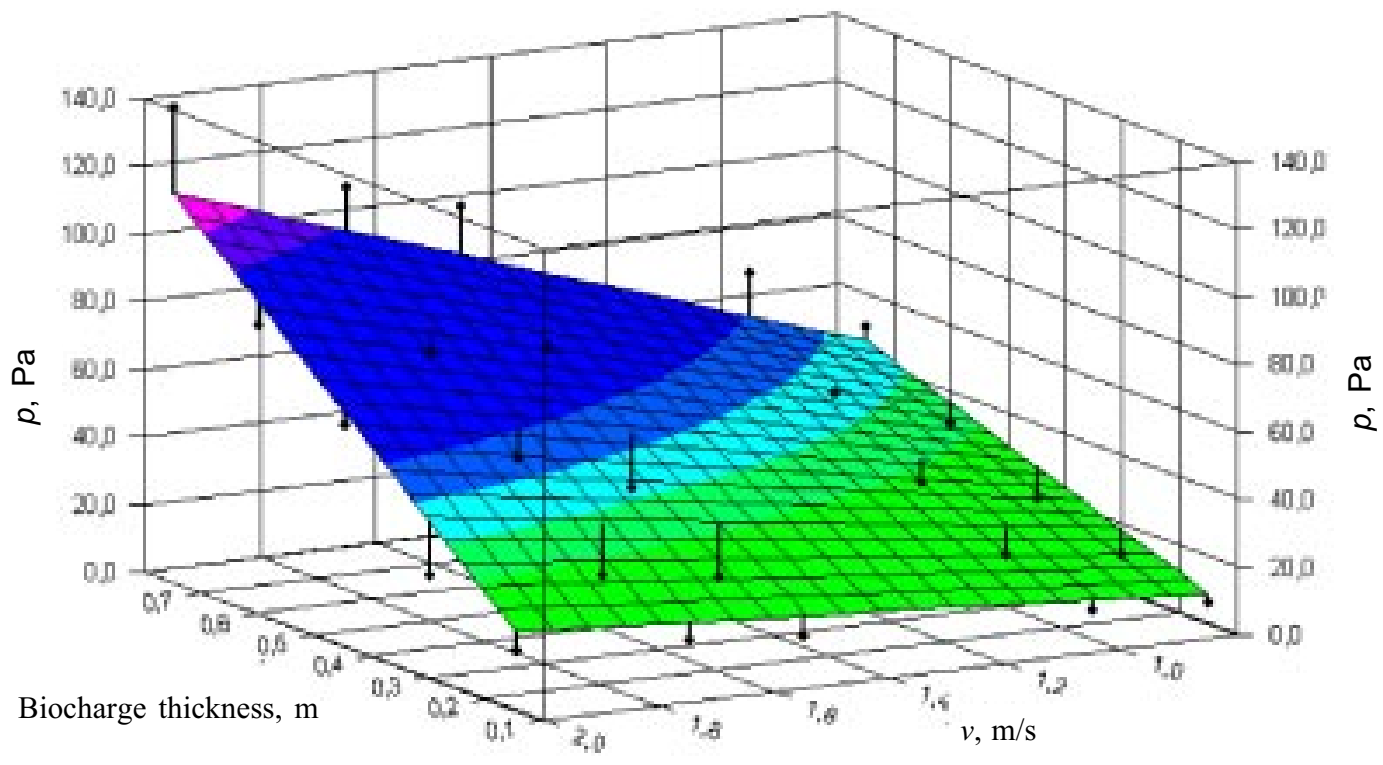

Fig 4. Dependence of aerodynamic resistance $(\mathrm{Pa})$ on the biocharge thickness $(\mathrm{m})$ and flow rate $(\mathrm{m} / \mathrm{s})$ 

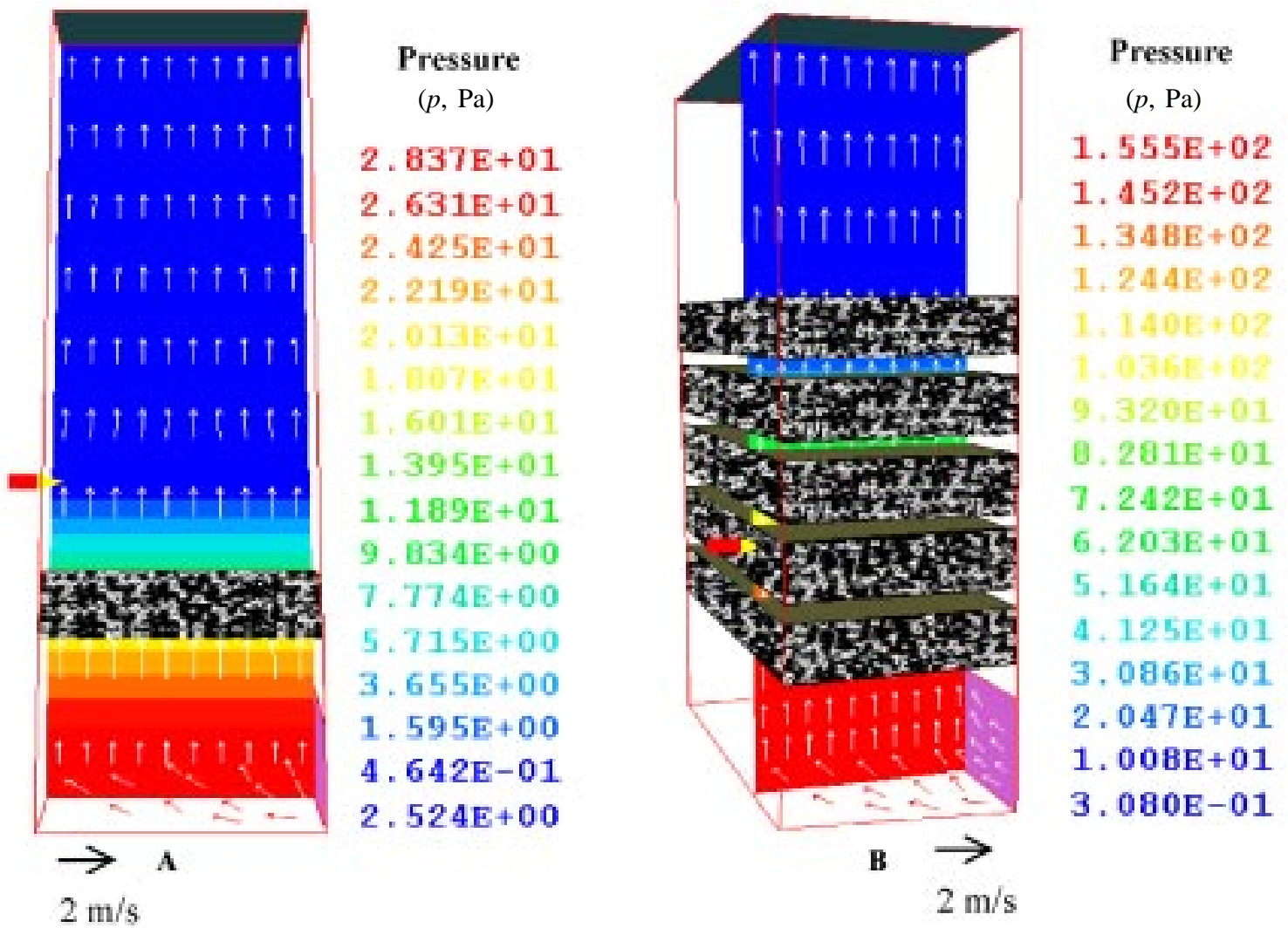

Fig 5. Pressure and velocity fields with fluid flowing through one (A) and five (B) layers

Fig 5 shows pressure and velocity fields with fluid flowing through one and five layers. Comparison of the results with the experimental data given in Fig 1 reveals an excellent agreement of the results.

The biofilter with activated bark charge was modelled with the help of the software Phoenics, Versions 3.2 and 3.5, Taking into consideration the porosity of the filter charge (75-80\%), the number (from 1 to 5 ) of layers $(150 \mathrm{~mm})$, the dynamics of aerodynamic processes, i e the velocity of the in-coming air and aerodynamic resistance of the charge, were modelled.

When modelling the aerodynamic processes occurring in the biofilter, the software Phoenics, Versions 3.2 and 3.5, was used. With the help of Phoenics, Versions 3.2 and 3.5, the dynamics of the in-coming flow velocity and aerodynamic resistance of the bark charge were modelled. When modelling aerodynamic processes in the biological air purification device, its geometric and initial characteristics of in-coming air flow were entered into the program. The geometric parameters of the device $(500 \cdot 480 \cdot 2000 \mathrm{~mm})$ and five equal $(150 \mathrm{~mm})$ charge layers were entered into the program (Fig 5). Other parameters corresponding to the experimental investigation device - the initial velocity of the in-coming air flow $(0,8$ to $2,0 \mathrm{~m} / \mathrm{s})$, coefficient of charge porosity (75-80\%) and its aerodynamic resistance (5 layers) were also entered into the program. The characteristics chosen in the course of mathematical modelling corresponded to those in the experimental device. Although the air-purification efficiency is the main characteristics of air-purification devices when developing them, the aerodynamic resistance of the charge is also very important. Thus in this work attention is first of all focused on the investigation and optimization of the aerodynamic processes and biocharge characteristics occurring in the biofilter.

The aerodynamic resistance of the filter charge was also modelled with the help of Phoenics, Version 3.5. For the task solution, the biocharge porosity (75-80\%) was selected to meet that in the experimental device charge. The aerodynamic resistance of the charge was modelled changing the number of charge layers (from 1 to 5) in the biofilter. Taking only one charge layer in the filter its aerodynamic resistance fluctuated rather insignificantly: from 28 to $3 \mathrm{~Pa}$. The highest aerodynamic resistance (up to $28 \mathrm{~Pa}$ ) was recorded in the charge layer at the entry to the airduct, and the lowest one (up to $3 \mathrm{~Pa})-$ at the air flow exit opening.

Without changing the initial conditions of the task (the velocity of the in-coming air flow of $2,0 \mathrm{~m} / \mathrm{s}$ ), the porosity of the charge (75-80\%), the dynamics of the aerodynamic resistance in the filter were analysed with five charge layers in the filter. Irrespective of the number of charge layers (one and then five layers), in the course of modelling the highest aerodynamic resistance in the biofilter was recorded at the five charge layers (156 Pa) (Fig 5).

Analogically to the results of experimental investi- 
gation, in the filter containing five charge layers the aerodynamic resistance decreases along the total length of the device with decreasing number of charge layers (from 156 to $10 \mathrm{~Pa}$ ). In the course of modelling it was determined that with four charge layers in the filter its aerodynamic resistance reached up to $124 \mathrm{~Pa}$, with three layers $-104 \mathrm{~Pa}$, with two layers $-72 \mathrm{~Pa}$, with one layer - $31 \mathrm{~Pa}$. After five charge layers the aerodynamic resistance in the filter was only $10-20 \mathrm{~Pa}$. Similarly to experimental investigation, a high reliability of the charge aerodynamic resistance was also obtained during investigation and modelling $\left(R^{2}=0,91\right)$. On the basis of the results of aerodynamic processes obtained in the course of modelling it could be stated that the air-purification process is intensive in the filter as a rather low dynamics of the in-coming air flow is recorded and that the charge aerodynamic resistance has little impact on the air-purification process.

\section{Conclusions}

1. The highest resistance of the filter charge (up to $140 \mathrm{~Pa}$ ) was recorded before all the five charge layers. Decreasing number of the charge layers resulted in gradually decreasing aerodynamic resistance. By evaluating with the help of statistical methods, very high approximation reliability coefficients $\left(R^{2}\right)$ were obtained (up to 0,99).

2. The obtained results are used to calculate full characteristics of the flow with the help of Phoenics software package. The highest aerodynamic resistance in the filter was recorded in its bottom part before all the charge layers. Analogically to the results of experimental investigation in the filter containing five charge layers the filter aerodynamic resistance gradually decreased with decrease in the number of charge layers (from 156 to $10 \mathrm{~Pa})\left(R^{2}=0,91\right)$.

3. By solving regression equations, the empirical expression of the filter aerodynamic resistance was obtained. Knowing the values of the biofilter (the height of the charge, its aerodynamic resistance, velocity of the air flow), the empirical and mathematical expression of the filter efficiency was found and in future it will enable theoretical calculation and selection of proper parameters of the device and to reach maximum efficiency of air purification.

\section{References}

1. Aerov, M. E.; Todes, O. M.; Narinski, D. A. Installation with the stationary charge. Chemical Engineering, 1979, p 176.

2. Carman, P. Fluid Flow through Granular Beds. Chemical Engineering, 15, 1997, p 150-166.

3. Darcy, H. Libraire des Corps Imperiaux des Ponts et Chaussees et des Mines. Les Fontaines Publiques de la Ville Dijon, 1987, p 28-38 (in French).

4. Baltrènas, P.; Vaiškūnaite, R. Treatment of volatile organic compounds and their mixtures from an air stream by a biofilter. In: Proceedings of the First International Congress on Mechanical and Electrical Engineering and Technology and the Fourth International Conference on Marine Industry - MEET/MARIND'2002, Vol III, 2002, p 89-95.

5. Baltrènas, P.; Vaiškūnaitè, R. Biofilter treatment of volatile organic compounds. Book of abstracts and papers. In: Proceedings of the IV-th International Youth Environmental Forum ECOBALTICA'2002, 2002, p 54-59.

6. Baltrènas, P.; Vaiškūnaite, R. Biological air purification by using activated pine bark charge. Environmental Engineering, Vol X, No 2. Vilnius: Technika, 2002, p 70-76.

7. Baltrènas, P.; Spruogis, A.; Krasovicki, J. Air-Cleaning Granular Filter (Воздухоочистные зернистые фильтры). Vilnius: Technika, 1998. 239 p. (in Russian).

8. Hodge, D-S. Determination of mathematical model constants using specially designed mini-column biofilters. In: Proceedings of the USC-TRG Conference on Biofiltration. Los Angeles, California. October 5-6, 1995, p 53-70.

9. Douglas, S.; Devinny, J. S. Modeling removal of air contaminants by biofiltration. TRG Biofilter. Journal of Environmental Engineering, Vol 121, No 1, p 21-32.

10. Mirpuri, R.; Sharp, W. A. A predictive model for toulene degradation in a flat plate vapor phase reactor. In: Proceedings of the USC-TRG Conference on Biofiltration. Los Angeles, California. October 5-6, 1995, p 71-84.

11. Sterne, L. A. Mathematical Modelling of a Biofilter for BTEX. 1999, p 1248-1377.

12. Amanullah, M.; Farooq, S.; Viswanathan, S. Modeling and simulation of a biofilter. Industrial \& Engineering Chemical Research, 38 (7), 1999, p 2765-2774.

13. http://www.cham.co.uk

\section{EKSPERIMENTINIAI BIOFILTRO AERODINAMINIO PASIPRIEŠINIMO TYRIMAI IR MATEMATINIS MODELIAVIMAS}

\section{P. Baltrẻnas, R. Vaiškūnaitė, V. Špakauskas}

\section{S a n tra u k a}

Dèl ūkinès veiklos $\mathfrak{i}$ aplinkos orą gausiai išsiskiria įvairios organinès kilmès teršalai - butanolis, butilacetatas, metanolis, formaldehidas, fenolis, benzolas, toluolas, ksilolas ir kt. Jie $\mathfrak{i}$ aplinkos orą patenka iš įvairių maisto, chemijos, medžio apdirbimo pramonès įmonių, autotransporto, žemès ūkio ir pan. Šiems lakiesiems organiniams junginiams valyti iš oro būtina taikyti efektyvius ir nebrangius metodus. Vienas iš tokių yra biologinis oro valymas, pagristas gyvų mikroorganizmų veikla, naudojant biofiltrą su aktyvinta pušų žievių ikrova. Iki šiol atlikti eksperimentiniai tyrimai nèra galutinis šio biofiltro darbo ivertinimas. Labai svarbu filtro veikimo metu ivvertinti ir jo ikrovos aerodinamini pasipriešinimą. Remiantis tyrimų rezultatais nustatytas biofiltro poringumas, ikrovos aerodinaminio pasipriešinimo priklausomybė nuo sluoksnių skaičiaus, bei gautos pusiau empirinès filtro aerodinaminio pasipriešinimo išraiškos, kurias ateityje galima būtų taikyti konstruojant analogiškus biofiltrus.

Raktažodžiai: biofiltras, matematinis modelis, aerodinaminis pasipriešinimas, empirinè išraiška. 
ЭКСПЕРИМЕНТАЛЬНОЕ ИССЛЕДОВАНИЕ И МАТЕМАТИЧЕСКОЕ МОДЕЛИРОВАНИЕ АЭРОДИНАМИЧЕСКОГО СОПРОТИВЛЕНИЯ В БИОФИЛЬТРЕ

\section{П. Балтренас, Р. Вайшкунайте, В. Шпакаускас}

P е $з$ ю м е

В результате хозяйственной деятельности человека в атмосферу выбрасываются различные загрязнители органического происхождения: бутанол, бутилацетат, метанол, формальдегид, фенол, бензол, толуол и др. Эти летучие органические загрязнители попадают в атмосферу из различных предприятий пищевой, химической промышленности, деревообрабатывающих, транспортных, сельскохозяйственных предприятий и т. д. При очищении воздуха от этих загрязнителей необходимо применять эффективные и недорогие методы. Одним из таких методов является биологическая очистка воздуха. Экспериментальный биофильтр с активным слоем из сосновой коры был создан в Вильнюсском техническом университете им. Гедиминаса. Эффективность биофильтра при очищении воздуха от летучих органических загрязнителей в большой степени зависит от аэродинамического сопротивления. На основании результатов экспериментальных исследований была определена пористость фильтра, зависимость аэродинамического сопротивления от толщины фильтра, получены полуэмпирические зависимости, позволяющие по параметрам фильтра определить аэродинамическое сопротивление.

Ключевые слова: биофильтр, математическая модель, аэродинамическое сопротивление, полуэмпирические зависимости. 